\title{
Nutrition and Fitness: Mental Health, Aging, and the Implementation of a Healthy Diet and Physical Activity Lifestyle
}




\section{World Review of Nutrition and Dietetics}

\section{Vol. 95}

Series Editor

Artemis P. Simopoulos

The Center for Genetics, Nutrition and Health, Washington, D.C., USA

Advisory Board

Regina C. Casper USA

Victor A.Rogozkin Russia

Cuiqing Chang China

Leonard Storlien Sweden

Claudio Galli Italy Ricardo Uauy-Dagach Chile

Uri Goldbourt Israel Antonio Velázquez Mexico

C. Gopalan India Mark L.Wahlqvist Australia

Tomohito Hamazaki Japan Michel de Lorgeril France Paul Walter Switzerland Bruce A.Watkins USA 
5th International Conference on Nutrition and Fitness

Athens, June 9-12, 2004

\section{Nutrition and Fitness: Mental Health, Aging, and the Implementation of a Healthy Diet and Physical Activity Lifestyle}

Volume Editor

Artemis P. Simopoulos

The Center for Genetics, Nutrition and Health, Washington, D.C., USA

19 figures, 1 in color, and 26 tables, 2005 
Additional proceedings from the conference are published in volume 94 of this series

\section{Artemis P. Simopoulos}

The Center for Genetics,

Nutrition and Health

Washington, D.C. (USA)

Library of Congress Cataloging-in-Publication Data

International Conference on Nutrition and Fitness (5th : 2004 : Athens,

Greece)

Nutrition and fitness : mental health, aging, and the implementation of a healthy diet and physical activity lifestyle / volume editor, Artemis P.

Simopoulos. ; v. 95)

p. ; cm. - (World review of nutrition and dietetics, ISSN 0084-2230

Part 2 of the proceedings of the 5th International Conference on Nutrition and Fitness, held in Athens, June 9-12, 2004.

Includes bibliographical references and index.

ISBN 3-8055-7945-4 (hard cover : alk. paper)

1. Nutrition-Congresses. 2. Mental health-Nutritional aspects-Congresses. 3. Physical fitness-Congresses. 4. Nutritionally induced diseases-Congresses.

[DNLM: 1. Nutrition-Congresses. 2. Aging-physiology-Congresses. 3.

Diet, Mediterranean-Congresses. 4. Health Behavior-Congresses. 5. Health

Promotion-Congresses. 6. Physical Fitness-Congresses. 7. Primary

Prevention-Congresses. QU 145 I60153nbc 2005] I. Title: Mental health, aging, and the implementation of a healthy diet and physical activity lifestyle. II. Simopoulos, Artemis P., 1933- III. Title. IV. Series.

QP141.A1W59 vol. 95

[QP141]

$612.3 \mathrm{~s}-\mathrm{dc} 22$

$[612$

$$
2005013176
$$

Bibliographic Indices. This publication is listed in bibliographic services.

Disclaimer. The statements, options and data contained in this publication are solely those of the individual authors and contributors and not of the publisher and the editor(s). The appearance of advertisements in the book is not a warranty, endorsement, or approval of the products or services advertised or of their effectiveness, quality or safety. The publisher and the editor(s) disclaim responsibility for any injury to persons or property resulting from any ideas, methods, instructions or products referred to in the content or advertisements.

Drug Dosage. The authors and the publisher have exerted every effort to ensure that drug selection and dosage set forth in this text are in accord with current recommendations and practice at the time of publication. However, in view of ongoing research, changes in government regulations, and the constant flow of information relating to drug therapy and drug reactions, the reader is urged to check the package insert for each drug for any change in indications and dosage and for added warnings and precautions. This is particularly important when the recommended agent is a new and/or infrequently employed drug.

All rights reserved. No part of this publication may be translated into other languages, reproduced or utilized in any form or by any means electronic or mechanical, including photocopying, recording, microcopying, or by any information storage and retrieval system, without permission in writing from the publisher.

(C) Copyright 2005 by S. Karger AG, P.O. Box, CH-4009 Basel (Switzerland)

www.karger.com

Printed in Switzerland on acid-free paper by Reinhardt Druck, Basel

ISSN 0084-2230

ISBN 3-8055-7945-4 


\section{Dedication}

The proceedings of the conference are dedicated to the concept of positive health as enunciated by the Hippocratic physicians (5th century BC).

Positive health requires a knowledge of man's primary constitution (which today we call genetics) and of the powers of various foods, both those natural to them and those resulting from human skill (today's processed food). But eating alone is not enough for health. There must also be exercise, of which the effects must likewise be known. The combination of these two things makes regimen, when proper attention is given to the season of the year, the changes of the winds, the age of the individual and the situation of his home. If there is any deficiency in food or exercise the body will fall sick. 


\section{Olympian Ode 2004}

Lee Pinkerson

The Olympic games of Ancient Greece even more than athletic feats praise the spirit of life divine handed down from God through our ancestral line

In body and soul, in heart and mind the ways of goodness they refined celebrated and known by all the Greek world unified in this concept, there's no place for war

Where the will to live burns bright they try with all their might awakening grace to join them and take flight every four years at the great Olympic games

In the land of the wild olive branch the walnut and the honey bee embraced by a sea where the fish run free is a diet that is high in omega-3

The goats eat their fill of the plants on the hill so even the cheese has omega-3s

The ancients had the nourishment they'd need to make them strong and make them smart fill the air with song and excel in the arts their world did dance in harmony 
And the walls would melt away when together they would play where race and class no longer separate every four years at the great Olympic games

A millennium has come again the Olympics are back where they began let's remember all they truly are More than a game, they're a way of life a torch to guide us past painful strife for possessions will not take us very far But the food we eat and the work we do the way we treat each other and the planet too will show how sweet we greet the daytime star every four years at the great Olympic games

Lee Pinkerson wrote the lyrics and music for the Olympian song in February 2004 in honor of the 2004 Olympic Summer Games in Athens, and for the Fifth International Conference on Nutrition and Fitness. A CD recording of her singing and guitar performance was given to the conference program participants. She can be reached from her website at http://www.leepinkerson.com. 


\section{Commemorative 2004 Conference Medal}

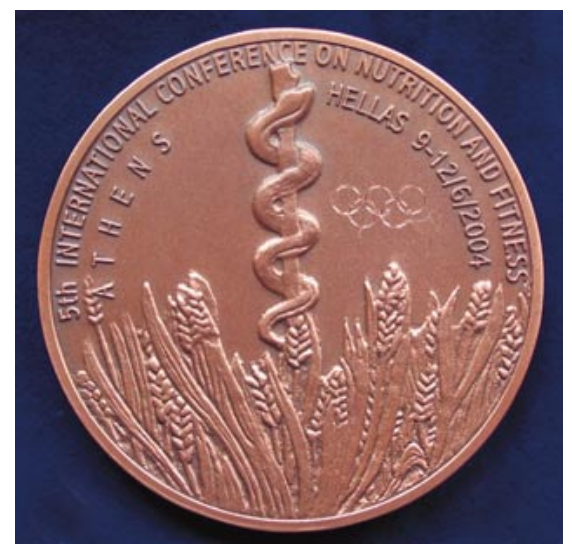

Front

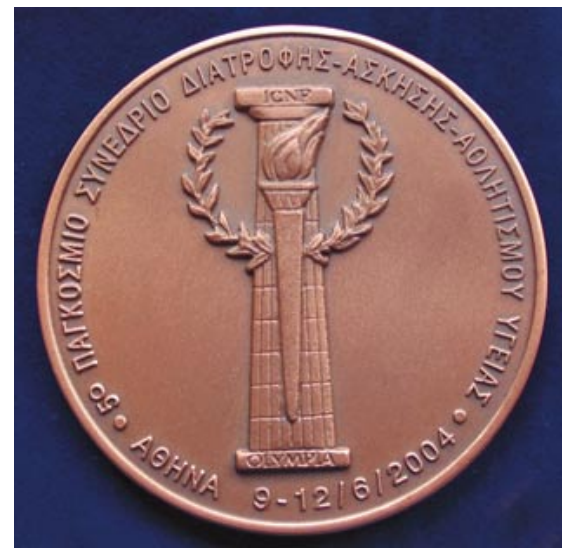

Back

Medal commemorating the 5th International Conference on Nutrition and Fitness. The medal is etched with the Olympic rings in honor of the 2004 Summer Olympic Games held in Athens, Greece. 


\section{Contents}

XII Conference Organization

XIV Preface

XXV Declaration of Olympia on Nutrition and Fitness

Ancient Olympia, Greece, May 28-29, 1996

Keynote Address

XXXIII Positive Health: Exploring Relevant Parameters

Ferris, A.E. (London)

Mental Health

1 Psychiatric Disorders, Mood and Cognitive Function: The Influence of Nutrients and Physical Activity

Casper, R.C. (Stanford, Calif.)

17 Nutrition and Schizophrenia

Peet, M. (Sheffield)

Aging, Osteoporosis, and Physical Activity

29 Managing Obesity after Menopause: The Role of Physical Activity Dubnov, G.; Berry, E.M. (Jerusalem) 
35 Osteoporosis: A Complex Disorder of Aging with Multiple Genetic and Environmental Determinants Ferrari, S.L. (Geneva)

52 Changes in Dietary Fatty Acids and Life Style as Major Factors for Rapidly Increasing Inflammatory Diseases and Elderly-Onset Diseases

Okuyama, H.; Ichikawa, Y.; Fujii, Y.; Ito, M.; Yamada, K. (Nagoya)

62 Physical Activity for Health: An Overview

Wahlqvist, M.L. (Melbourne)

73 Physical Inactivity Is a Disease

Lees, S.J.; Booth, F.W. (Columbia, Mo.)

Defining the Components of a Healthy Diet and Physical Activity for Health

80 What Is So Special about the Diet of Greece? The Scientific Evidence Simopoulos, A.P. (Washington, D.C.)

93 Balance of Omega-6/Omega-3 Essential Fatty Acids Is Important for Health. The Evidence from Gene Transfer Studies

Kang, J.X. (Boston, Mass.)

103 Dietary Prevention of Coronary Heart Disease: The Lyon Diet Heart Study and After de Lorgeril, M.; Salen, P. (Grenoble)

115 The Nicotera Diet: The Reference Italian Mediterranean Diet Fidanza, F.; Alberti, A. (Rome); Fruttini, D. (Perugia)

122 Wine and Health: Evidence and Mechanisms Urquiaga, I.; Leighton, F. (Santiago)

The Role of Government in Implementing a Healthy Diet and Physical Activity Lifestyle

140 Implications of Food Regulations for Novel Foods. Safety and Labeling Lupien, J.R. (Amherst, Mass.)

151 A New Look at Intersectoral Partnerships Supporting a Healthy Diet and Active Lifestyle: The Centre of Excellence in Functional Foods, Australia, Combining Industry, Science and Practice

Tapsell, L.C.; Patch, C.S.; Gillen, L.S. (Wollongong) 
162 Why a Global Strategy on Diet, Physical Activity and Health? Waxman, A. (Geneva)

167 Nutrition and Fitness Policies in the United States Lee, P.R. (Stanford, Calif.)

177 Author Index

178 Subject Index 


\section{Conference Organization}

\section{Conference Chair}

Artemis P. Simopoulos, MD (USA)

\section{Conference Co-Chairs}

George P. Chrousos, MD (USA/Greece)

Konstantinos N. Pavlou, DSc (Greece)

\section{Executive Committee}

Frank W. Booth, PhD (USA)

Peter Bourne, MD (USA/UK)

Regina C. Casper, MD (USA)

Cuiqing Chang, MD, PhD (China)

Nicholas T. Christakos, Esq (USA)

George P. Chrousos, MD (USA/Greece)

Raffaele De Caterina, MD, PhD (Italy)

Nikos Filaretos (Greece)

C. Gopalan, MD, PhD, DSc (India)

Sotiris Kitrilakis (Greece)

Demetre Labadarios, MD, PhD

(South Africa)

Alexander Leaf, MD (USA)

Philip R. Lee, MD (USA)

Federico Leighton, MD (Chile)
Harumi Okuyama, PhD (Japan)

José Ordovas, PhD (USA)

Costas Parisis, MD, PhD (Greece)

Konstantinos N. Pavlou, DSc (Greece)

Artemis P. Simopoulos, MD (USA)

Eliot Sorel, MD (USA)

Panos G. Stamatopoulos, MD (Greece)

Leonard Storlien, $\mathrm{PhD}$ (Sweden)

Bill Toomey (USA)

A. Stewart Truswell, MD, DSs

(Australia)

Mark L. Wahlqvist, MD, PhD

(Australia)

Clyde Williams, PhD (UK)

\section{Local Committees in Greece}

\section{A. Organizing Committee}

Chair: Panos G. Stamatopoulos

Co-chair: Leonidas N. Seitanidis

Secretaries: Evagelia Maglara

Kalliopi - Anna Poulia

Treasurer: Kostantinos N. Pavlou

Members: Elena Averoff

Antonia Georgiopoulou 
Maria Hassapidou

Stavros Kavouras

Sotiris Kitrilakis

Saki Kypreou

Konstantinos Natsis

George P. Rontoyannis

Nikos Terzidis

Nikos Yiannakouris

\section{B. Scientific Committee}

Christos Aravanis

Eleni Avlonitou

Panos Behrakis

Athina Bei

Garifalia Emmanouil

Dimitrios Hassiotis

Nikos Katsilambros

Denis Kokkinos

Manousos Konstantoulakis

Maria Liparaki

Antonis Maillis

Pantelis Nikolaou

George P. Rontoyannis

Yiannis Steriotis

Pavlos Toutouzas

Alexandros Tsopanakis

\section{Conference Organized by}

The Center for Genetics, Nutrition and Health

2001 S Street, N.W., Suite 530

Washington, DC 20009 (USA)

Tel. +1 2024625062

Fax +1 2024625241

E-Mailcgnh@bellatlantic.net

\section{Major Sponsors}

The Center for Genetics, Nutrition and Health

Stavros S. Niarchos Foundation

\section{Under the Patronage of}

Food and Agriculture Organization of the United Nations

International Union of Nutritional

Sciences

International Olympic Academy

Committee for Athens 2004 Olympics

Hellenic Ministry of Education

Hellenic Ministry of Sports

\section{Conference Sponsors}

AstraZeneca

Belovo

California Walnut Commission/Walnut

Marketing Board

Harokopio University

Hellenic American Union

Hellenic Football Federation

Mars, Inc.

Minami Nutrition/MorEPA/Barleans

National Dairy Council (USA)

Nutrilite Health Institute

World Cancer Research Fund

International/American Institute for

Cancer Research

Unilever

\section{In Co-Operation with}

Hellenic Association of Sports

Medicine

Hellenic Institute of Sports Research, Athens

Hellenic Heart Foundation

National Institute on Alcohol Abuse and Alcoholism, NIH, USA

Onassis Cardiosurgery Center, Athens

University of Thessaly 


\section{Preface}

The Fifth International Conference on Nutrition and Fitness was held in Athens, Greece, on June 9-12, 2004. This being the year when the Olympic Games were returned to the country of their origin, the keynote address given by Elizabeth Ferris, MD, a former Olympic medalist and Vice President of the World Olympians Association, was entitled 'Positive Health - Exploring Relevant Parameters'.

The goals and objectives of the conference were to:

- Review and critique the latest scientific information on nutrition and fitness, taking into consideration genetic endowment, adaptation throughout the life cycle and the nutritional factors that contribute to fitness, specifically, the effect of the various dietary sources of energy on energy expenditure, exercise and performance.

- Determine the relationship of nutrition and fitness to chronic diseases, particularly, the metabolic changes that occur with the type and amount of physical activity for the prevention and management of cardiovascular disease, mental health, obesity, osteoporosis, diabetes and cancer.

- Consider the psychosocial and other determinants of physical activity throughout the life cycle including intervention strategies, and emphasize healthy lifestyles consistent with proper nutrition and fitness.

- Stimulate national governments and the private sector to coordinate and thus maximize their efforts to develop programs that encourage proper nutrition and participation in sports activities by all, throughout the life cycle, to achieve their potential in fitness and thus increase the pool of young athletes, from whom the elite athlete will be forthcoming. 
- Develop strategies for the distribution and implementation worldwide of the 1996 'Declaration of Olympia on Nutrition and Fitness' for the New Millennium, through the establishment of regional committees.

The conference consisted of 10 sessions of oral presentations and 2 poster sessions in which 110 abstracts were presented. Scientists from 46 countries participated representing the continents of Africa, Asia, Australia/New Zealand, Europe, and North and South America. The proceedings of the conference are presented in two volumes in this series. Volume 94 is entitled Nutrition and Fitness: Obesity, the Metabolic Syndrome, Cardiovascular Disease, and Cancer. Volume 95 is entitled Nutrition and Fitness: Mental Health, Aging, and the Implementation of a Healthy Diet and Physical Activity Lifestyle. Both volumes begin with the Dedication to the concept of 'Positive Health', the 2004 Olympian Ode by Lee Pinkerson, the Commemorative Medal, the Conference Organization, the Preface, the 1996 'Declaration of Olympia on Nutrition and Fitness' and the Keynote Address entitled 'Positive Health - Exploring Relevant Parameters' by Elizabeth Ferris, MD. The address sets the stage for the importance of physical activity in health and the deleterious effects of inactivity. The Olympic spirit and the Olympic games celebrate achievement and the individual. It is expected that in the 21 st Century scientific information will be developed that will deliver individualized genotype-based health care. A conscious effort must be made to develop in all dimensions the environment in which the human genome finds its optimal expression. This, of course, represents a complete circle returning and recognizing the Hippocratic concept of 'positive health' of 2500 years ago, based on the individual and in the 21 st Century proving it through molecular biology.

Volume 94 entitled Nutrition and Fitness: Obesity, the Metabolic Syndrome, Cardiovascular Disease, and Cancer presents the papers on obesity, syndrome $\mathrm{X}$, diabetes, cardiovascular disease, and cancer. The papers on obesity emphasize the severe burden of obesity worldwide and the need to have a classification system of obesity that relates to the specific population from whence the data were obtained that relate obesity to morbidity and mortality. Kanazawa and his coworkers in their paper 'Criteria and Classification of Obesity in Japan and Asia-Oceania Region' presented by Shuji Inoue, clearly discuss the fact that these populations are at risk for the development of chronic diseases at lower body mass index (BMI) levels than Caucasians.

Cuiqing Chang, in her paper on 'Exercise and Obesity in China', discusses the role of physical activity or exercise on the occurrence of obesity, specifically the function and effectiveness of exercise on weight reduction and a prescription for weight loss. China has developed guidelines and recommendations for the classification of obesity. Kafatos et al., in their paper on 'Obesity in 
Childhood: The Greek Experience', presents the Greek experience, a specific program in which the teacher uses 'customized' classroom materials that include a physical activity component and parental involvement. The program is one of the few programs in Europe to have reported positive results in terms of obesity and physical fitness in primary schools in Crete. Educational interventions in schools have great potential needed to tackle the urgent problems of dietary and lifestyle choices contributing to the blight of childhood obesity and its co-morbidities.

Aaron and coworkers, in their paper 'Epidemiology of Physical Activity from Adolescence to Young Adulthood', provide a synthesis of the current knowledge about the epidemiology of physical activity during the transition from adolescence to young adulthood. The paper on 'Adolescent Obesity and Physical Activity' by Hwalla's group describes the study carried out in Lebanon. The results of this first national population-based study show that adolescent obesity is largely caused by lack of physical activity, and the boys fair worse than the girls. The authors recommend multi-component intervention strategies at the societal and individual levels for weight control that include health professionals, families, schools, businesses, and health care organizations, in order to increase programs and opportunities for physical activity. Pavlovic and colleagues indicate in their paper titled 'Nutrition and Physical Activity of the Population in Serbia' that for both children and adults, inadequate nutrition and physical activity are related to an increase in risk factors and the need for health promotion programs. Drs. Andreoli and De Lorenzo, in their paper on 'Physical Activity and Body Composition', emphasize the importance of body composition to evaluate health status in nutritional terms both at the population level and for the individual.

The etiology of the metabolic syndrome is not well understood. The approach to its treatment includes lifestyle modification along with pharmacological therapy, as appropriate. Labadarios, in his paper 'Syndrome X: Clinical Aspects' presents an overview of syndrome $\mathrm{X}$ and its relationship to obesity, diabetes and cardiovascular disease.

Tataranni's paper is on 'Metabolic Syndrome: Is There a Pathophysiological Common Denominator? Lessons Learned from the Pima Indians.' In addition to clinical physiologic and molecular studies, he carried out a factor analysis designed to statistically test the hypothesis that insulinemia, body size, lipids and blood pressure may result from a single etiologic abnormality. The study failed to identify a single factor underlying the correlation structure of these variables. As a result, Tatarani concluded that molecular and epidemiologic evidence from the studies in Pima Indians suggests that the abnormalities constituting the metabolic syndrome are the result of largely independent physiologic processes. Therefore, clinical treatment and prevention strategies based on the 'metabolic 
syndrome' hypothesis may prove suboptimal compared with treatment of the individual components.

Storlien et al.'s paper on 'Lifestyle-Gene-Drug Interactions in Relation to the Metabolic Syndrome' emphasizes the fact that obesity drives the metabolic syndrome and the polygenic nature of disorders like obesity means that there will be a need for many approaches that will include lifestyle changes along with pharmaceutical support, greatly dependent upon understanding the individual's genetic make up. Common dietary components, such as fatty acids and simple sugars, are potent gene regulators on many 'pharmaceutical' metabolic syndrome targets. Novel drugs are almost certain to interact strongly with dietary and other lifestyle variables. Storlien and coworkers refer to thiazolidinediones, the only really new class of anti-diabetic therapy introduced in the past few years, as a prime example. This class of drugs targets the nuclear hormone receptor PPAR $\gamma$ and the relationship between weight gain and PPAR $\gamma 2$ polymorphism is highly dependent on the dietary polyunsaturated/saturated $(\mathrm{P} / \mathrm{S})$ ratio. There are strong indications that modulating muscle metabolism would be of enormous benefit in prevention and treatment of obesity. While exercise training clearly moves muscle morphology and metabolism in a beneficial direction, there is marked genetic heterogeneity in both compliance and response to exercise training in the needy population, i.e. those with the metabolic syndrome. Therefore, it is necessary to understand how drug/diet interactions might act as a multiplier for the beneficial effects of exercise, thus enhancing both the health benefits and the likelihood of compliance.

Donati and Iacoviello's paper on 'Coronary Heart Disease, Genetics, Nutrition and Physical Activity' discusses gene polymorphisms and their interactions with diet and physical activity as they affect lipids, hemostatic and vascular factors. Drs. De Caterina and Madonna in their paper 'Role of Nutrients and Physical Activity in Gene Expression' review the subject of how the rapid evolution of vascular and molecular biology in the last 20 years has completely transformed our understanding of the development of coronary heart disease. The authors discuss their studies on the role of omega-3 fatty acids in modulating the immune system and suppressing vascular cell adhesion molecules. Physical activity protects or reduces the risk for the development of cardiovascular disease by indirectly reducing a number of cardiovascular disease risk factors such as high blood pressure, hypercholesterolemia, obesity and diabetes, and also promoting direct anti-atherogenic vascular responses through the action of increased laminar shear on endothelial cells. Recent advances resulting from studies of vascular biology using molecular biology techniques are revealing a previously unsuspected complexity of the vascular responses to nutrients and physical activity, and are providing molecular explanations on how healthy or unhealthy lifestyles interact with our genes, permitting or 
inhibiting the expression of the phenotype, even in the presence of unfavorable genes. This has serious implications in providing solid scientific background for preventive strategies that will focus on healthy nutrition, physical activity and life habits. Rontoyannis' paper 'Physical Activity and Hypertension: An Overview' focuses on the benefits of exercise in the control of blood pressure. Rontoyannis emphasizes that walking may be the best and safest aerobic physical activity. The underlying mechanisms responsible for an exercise-induced reduction in blood pressure remain unclear. Possible mechanisms include the lower cardiac output and peripheral vascular resistance at rest; and at any given submaximal levels of work, the reduction in blood catecholamine levels and plasma renin activity, the altered renal function leads to increased elimination of sodium resulting in a reduction of blood volume; and the reduction in insulin levels and insulin resistance, among others. The next paper by Leaf and colleagues, on 'Omega-3 Fatty Acids and Ventricular Arrhythmias' presents a thorough review and new information on how omega-3 fatty acids decrease ventricular arrhythmia and sudden death. Leaf showed that the effect of omega -3 fatty acids is to stabilize electrically every contractile cell in the heart. Recent data on the prevention of fatal ventricular arrhythmia in humans indicate that cardiologists should prescribe $1 \mathrm{~g}$ of omega-3 fatty acids (EPA + DHA) to their patients, who already had one episode of heart attack, in addition to other medications.

The studies on the beneficial effects of the omega- 3 fatty acids in both the primary and secondary prevention of coronary heart disease demand the development of methods to measure circulating fatty acids at the population level. Only a few studies have reported data on the fatty acid composition of circulating lipids in confirmation of dietary intake. Marangoni's group, in their paper 'A Method for the Direct Evaluation of the Fatty Acid Status in a Drop of Blood from a Fingertip in Humans: Application to Population Studies and Correlations with Biological Parameters' discuss their method to determine fatty acids. The method has been validated, is rapid, less expensive than other methods, does not require health personnel, is applicable to population groups, and provides valuable information on the impact of dietary habits, lifestyles and fatty acid supplementation on blood fatty acids.

There has been a lack of consistency in the data relating diet and cancer in cohort studies, most likely due to the way in which dietary intake has been measured. All methods of dietary assessment are associated with measurement error. This fact attenuates estimates of disease risk and reduces statistical power so that a relation between diet and disease may be obscured. In her paper 'Measurement Error in the Assessment of Interaction between Dietary and Genetic Factors in Cohort Studies of Cancer,' Bingham points out that the effect of error on regression dilution and estimated sample size is compounded when 
attempts are made to assess the interactions between dietary and genetic polymorphisms in assessing risk. Traditionally repeat results from the method used in a cohort, usually a Food Frequency Questionnaire, are compared with those from another assessed more accurate method. However, errors between methods may be correlated so that results from the reference method are not independent of those derived from the test method, thus violating a critical requirement of this procedure. Bingham therefore assessed dietary intake using both a food frequency questionnaire and a detailed seven day diary of food and drink in 13,070 women. The hazard ratio for breast cancer for each quintile increase of energy adjusted fat was strongly associated with saturated fat intake measured using the food diary, but not with saturated fat using the food frequency questionnaire. These results support the view that measurement error might explain the lack of relationship between fat and breast cancer risk in previous prospective studies using data obtained by Food Frequency Questionnaires. Muñoz Rivera and coworkers in their paper 'Cancer Frequency in Poor Rural Communities Consuming a Very Limited Diet' conclude that in Mexico, dietary changes do not show a relationship with cancer, whereas they do in other chronic diseases such as obesity and diabetes. This could be due to the age of the indigenous population (the population is young) or to the level of physical activity. In the next paper 'Omega-6/Omega-3 Polyunsaturated Fatty Acids Ratio and Breast Cancer,' Bougnoux and colleagues clearly demonstrate the importance of dietary components in the etiology and development of breast cancer. In their studies, they found alpha-linolenic acid and docosahexaenoic acid to be inversely related to the risk of breast cancer, where the trend was opposite for linoleic acid, arachidonic acid, and for the omega-6/omega-3 long chain fatty acids. The higher the omega- $6 /$ omega -3 ratio, the higher the estimated relative risk of breast cancer. Similar results were obtained by Tavani et al. In their paper 'Fish, $\omega-3$ Polyunsaturated Fat Intake and Cancer at Selected Sites' they investigated the relation between fish consumption and omega -3 polyunsaturated fatty acids, and the risk of selected neoplasms. Their data show that consumption of even small amounts of fish decreases the risk of several cancers, especially of the gastrointestinal tract. Physical activity is an important component of healthy lifestyles. Willer, in his paper 'Cancer Risk Reduction by Physical Exercise' reviews the evidence of the effect of physical activity on cancer development and concludes that there is enough evidence to recommend physical activity for life (long-term) for the prevention of certain cancers.

Volume 95 is part 2 of the proceedings, Nutrition and Fitness: Mental Health, Aging, and the Implementation of a Healthy Diet and Physical Activity Lifestyle. Nutrition and physical activity influence mental health. Among the fatty acids, the omega- $6 /$ omega -3 ratio and omega -3 fatty acids have been 
studied in patients with depression, schizophrenia, bipolar disorders, attention deficit disorders and dementia. Casper in her paper on 'Psychiatric Disorders, Mood and Cognitive Function: The Influence of Nutrients and Physical Activity' reviews studies that have related variations in the amount of protein, amino acids, carbohydrates, and polyunsaturated fatty acids to mood changes. Efficacy data on omega-3 fatty acids used as adjunct or in monotherapy in unipolar and bipolar depressive disorders are critically reviewed. Evidence now exists that prenatal exposure to wartime famine may have had a bearing on the development of psychomorbidity, in particular the schizophreniform disorders. Casper also presents an evaluation of the literature that addresses the relationship between regular physical activity in the form of exercise, in relation to mood and cognitive function. Increasing evidence that psychiatric disorders are not only multifactorial, but also multigenic diseases, suggests that genetic variation could emerge as an important variable mediating the effects between nutrition and mental disorders.

Peet, in his paper 'Nutrition and Schizophrenia' presents a critical review and evaluation of the literature on the role of dietary components on schizophrenia. In addition to omega-3 fatty acid intervention studies, Peet reviews the evidence that a low saturated fat and low sugar diet may be beneficial, but this has not been tested in controlled clinical trials.

Dubnov and Berry in their paper 'Managing Obesity after Menopause: The Role of Physical Activity' carried out a Medline and manual search for articles on overweight and obesity following menopause, the risks and methods of treatment emphasizing physical activity. Their results show that among postmenopausal women, physical activity is a major mode of treatment and postmenopausal women should engage in physical activity daily, because overweight and obesity occurs in over $50 \%$ of that population.

Ferrari, in his paper 'Osteoporosis: A Complex Disorder of Aging with Multiple Genetic and Environmental Determinants' reviews the genetic and environmental factors influencing bone turnover and bone density, particularly estrogen-deficient women and those with low calcium intake and genes associated with vertebral bone mass and size in adult men. The usefulness of the gene variants or polymorphisms in predicting fracture risk and response to therapy remains to be demonstrated.

Inflammation is now considered to be at the basis of many chronic diseases and conditions including aging. Okuyama and coworkers, in their paper 'Changes in Dietary Fatty Acids and Life Style as Major Factors for Rapidly Increasing Inflammatory Diseases and Elderly-Onset Diseases' indicate that the major elderly-onset diseases in Japan are cancer, atherosclerosis related diseases and pneumonia. Elevation of inflammatory tone is a likely major cause for these diseases, which is brought about by excessive intake of linoleic 
acid (LA, omega-6) and enhanced arachidonic acid (AA, omega-6) cascade. Because omega -6 and omega -3 fatty acids and their metabolites (eicosanoids, inflammatory mediators) are competitive at many steps of enzyme reactions and receptors, not only the absolute amounts of omega -6 and omega -3 fatty acids, but their balance, particularly the omega-6/omega -3 ratio, is an important factor in regulating the inflammatory tone and related diseases. Changes in life style, such as decreased physical activity and overnutrition in older populations lead to unfavorable energy balance. Reduced frequency of skin exposure to environmental changes (temperature, sweating conditions) is a likely cause for enhanced skin and mucosal sensitivity to allergens in younger populations. These environmental factors could be modified by changing the life style, besides choosing foods to keep a good omega-6/omega-3 fatty acid balance.

Despite the enormous interest in uncovering longevity genes in humans, the results have been elusive. The effects of physical activity in delaying aging are promising whereas the effects of caloric restriction in humans are now being systematically investigated in three major studies funded by the National Institutes of Health (Bethesda, Md., USA) at the Pennington Biomedical Research Center in Baton Rouge, La., at Tufts University in Boston, Massachusetts, and at Washington University in St. Louis, Mo., USA. Caloric restriction (CR) is the only mechanism known to extend life span and retard age-related chronic diseases. This has been proven repeatedly in a variety of species including rats, mice, fish, flies, worms and yeast. CR reduces metabolic rate and oxidative stress, improves insulin sensitivity and stress response, and alters neuroendocrine and sympathetic nervous system function. Whether any, or all of, these changes provide the mechanism for life-span extension effect is presently unresolved. Furthermore, the effects of prolonged CR on biomarkers of aging in nonobese humans are unknown. In experiments of nature, humans have been subjected to periods of non-volitional partial starvation. However, in almost all of these cases the diets have been of poor quality. The absence of adequate information on the effects of good quality CR diets in non-obese humans reflects the difficulties involved in conducting long-term studies in an environment so conducive to overfeeding.

Diet and physical activity cannot be disassociated from each other, not only because of energy need, but also because of the profile of food components - macronutrients, micronutrients and phytonutrients - which allow, sustain and optimize movement. In his paper 'Physical Activity for Health: An Overview' Wahlqvist states that preventive physical activity can address the burden of disease and longevity. Therapeutic physical activity can reduce the problems of sarcopenia and frailty, or the growing burden of nutritional and metabolic disease, and of senescence. We must seek a unifying strategy for 
health advancement and for optimal health that is sustainable. In order to accomplish that, we must involve ourselves continuing as our own machines, moving, thinking, socializing, and integrated with the natural world.

There is now enough evidence to consider physical inactivity a disease, because epidemiologic studies provide robust evidence that physical inactivity is strongly associated with an enhanced risk of premature chronic diseases and death. Lees and Booth in their paper 'Physical Inactivity Is a Disease' provide a concise review of the evidence of the importance of physical activity in the prevention of many diseases that affect modern humans. There is now enough evidence to define the components of a healthy diet as well as the components of physical activity at the population level. At the same time, there are exciting research data defining the type and frequency of genetic variation and how genetic differences influence dietary response and how diet, nutrients and exercise influence gene expression.

In her paper 'What Is So Special about the Diet of Greece? The Scientific Evidence,' Simopoulos provides scientific evidence and emphasizes the importance to follow a diet consistent in composition to the diet upon which humans evolved, and their genes were programmed to respond. In this respect, traditional diets do not differ much or are similar in their composition relative to antioxidants, essential fatty acids and a balanced omega-6/omega-3 ratio. The latter is very important because during evolution, the ratio was balanced 1:1 whereas this ratio is $16.8: 1$ in the diet of the United States and 15:1 in the diet of Northern Europe, but 4:1 in Japan and 30:1 in India. What makes the diet of Crete different from the other Mediterranean diets is the balanced omega-6/omega -3 ratio of $1-2 / 1$. The Greek diet, balanced in the essential fatty acids and high in antioxidants, is the diet that is the closest to the diet on which humans evolved. In his paper 'Balance of Omega-6/Omega-3 Essential Fatty Acids Is Important for Health: The Evidence from Gene Transfer Studies' Kang provides evidence at the molecular level of the importance of the balanced omega-6/omega-3 ratio. Furthermore, de Lorgeril and Salen in their paper 'Dietary Prevention of Coronary Heart Disease: The Lyon Heart Study and After' clearly show the fact that a modified diet of Crete with a ratio of 4:1 of linoleic to alphalinolenic acid decreased mortality risk by $70 \%$. Similar results have been observed in studies in India showing that the lower the ratio, the lower the risk for total mortality, coronary heart disease mortality, and sudden death. Fidanza and coworkers in their paper 'The Nicotera Diet: The Reference Italian Mediterranean Diet' describe the Nicotera Diet as a model for the Italian population and present a food guide modeled after the Greek Column Food Guide, but in the form of a Greco-Roman Temple rather than the 
Pyramid Food Guide developed by the US Department of Agriculture and the US Department of Health and Human Services. Wine is an important component in the diets among the Mediterranean countries as well as in South America. Urquiaga and Leighton's paper on 'Wine and Health: Evidence and Mechanisms' is an excellent review of the status of research on wine. Decreased cardiovascular disease and longevity are epidemiological parameters associated with wine consumption. Recent evidence suggests that longevity could also be the direct consequence of phenolics activating histone deacetylation, a gene expression regulatory mechanism proposed to explain the longevity associated with caloric restriction.

Over the last 15 years, new concepts have evolved about food's functions. Functional foods are thought to be foods that improve bodily functions, help prevent various non-communicable diseases, or help in the cure of some conditions. There has been a wide range of research into the beneficial effects of foods and food ingredients, beyond essential nutritional requirements for macronutrients and essential vitamins and minerals. Lupien's paper on 'Implications of Food Regulations for Novel Foods: Safety and Labeling' includes a concise description of the regulatory schemes in the European community, the United States, Australia, New Zealand, Japan and China. The paper provides examples of current functional food benefits and claims. The need for adequate data is emphasized in order to substantiate claims and benefits to meet current and possible future regulatory requirements.

Australia is one of the first countries to establish a Centre of Excellence in Functional Foods. Tapsell and coworkers in their paper 'A New Look at Intersectoral Partnerships Supporting a Healthy Diet and Active Lifestyle: the Centre of Excellence in Functional Foods, Australia. Combining Industry, Science and Practice' outline the basis for the scientific program at the Centre of Excellence in Functional Foods, indicating how this may support the development of healthy diets and healthy lifestyles. Research at the center takes the form of strategic (government funded) and commercial (industry funded) projects.

The World Health Organization (WHO) has recognized the importance of nutrition and physical activity. In May 2004, at the World Health Assembly, member nations voted on WHO's Global Strategy on Diet, Physical Activity and Health that appears in the paper by Amalia Waxman. The 'Nutrition and Fitness Policies in the United States' are discussed by Lee who reviews the programs and policies in the United States and the reasons for the difficulties in their implementation. It will be necessary to develop a broad-based population approach that includes improving accessibility of nutrition information, education, and services; strengthening and sustaining broad-based community 
programs and partnerships, and working with the nation's public and private elementary and secondary schools. Similarly, a population-based approach to physical activity is needed.

These proceedings should be of interest to physicians, nutritionists, exercise physiologists, geneticists, dietitians, food scientists and policy makers in government, private industry and international organizations.

Artemis P. Simopoulos, MD 


\title{
Declaration of Olympia on Nutrition and Fitness
}

\author{
Ancient Olympia, Greece, May 28-29, 1996
}

\section{Background}

The International Conferences on Nutrition and Fitness are held in Greece every 4 years in the spring prior to the Olympic Games. Following each conference, a declaration is developed at a special meeting at the International Olympic Academy to update advice on nutrition and fitness for all. The proceedings of the conferences are published in the scientific literature listed on pages XXXI-XXXII.

The Third International Conference on Nutrition and Fitness was held at the Olympic Athletic Center of Athens 'Spyros Louis', May 24-27, 1996, in Athens, Greece. Four hundred and eighty participants from 31 countries attended the conference. Following the conference, an international panel composed of members of the conference Executive Committee, along with the session chairs, met at the International Olympic Academy at Ancient Olympia to develop the 'Declaration of Olympia on Nutrition and Fitness' for 1996.

This international panel agreed that on the occasion of the 100th anniversary of the Olympic Games, it is important to reaffirm the concepts of positive health postulated by Hippocrates and to reassess their relevance to the Olympic ideal and the health of the world's population. The concept of Positive Health, as enunciated by Hippocrates, is based on the interaction of genetics, diet and physical activity.

'Positive health requires a knowledge of man's primary constitution (which today we call genetics) and of the powers of various foods, both those natural to them and those resulting from human skill (today's processed food). But eating alone is not enough for health. There must also be exercise, of which the effects must likewise be known. The combination of these two things makes regimen, when proper attention is given to the season of the year, the changes of the winds, the age of the individual and the situation of his home. If there is any deficiency in food or exercise the body will fall sick' (480 BC). 


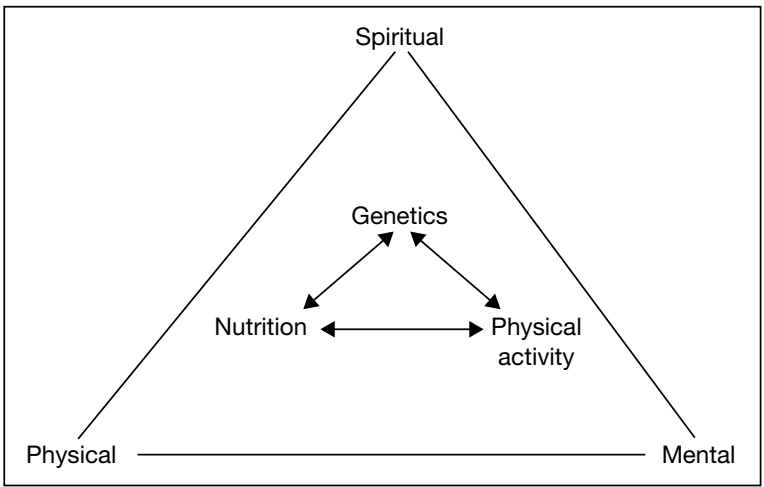

Fig. 1. The interaction of genetics, nutrition and physical activity influences the spiritual, mental and physical aspects of health.

Among the Greeks, the concept of positive health was important and occupied much of their thinking. Those who had the means and the leisure applied themselves to maintaining positive health, which they often conceived esthetically, and to this end put themselves into the hands of trainers who subjected them to a regimen. Training for war and athletic competition was of course well known among them. Health was an excellence in its own right, the physical counterpart and condition of mental activation. The details of the regimen practiced for health were an important part of Greek medicine. The Concept of Positive Health may be represented by a triangle involving genetics, nutrition and physical activity that influence the spiritual, mental and physical aspects of health (fig. 1).

\section{Genetic Variation, Nutrition, Physical Activity, and Health}

The interaction between genetic and environmental factors influences human development and is the foundation for health and disease. Genetic factors define susceptibility to disease and environmental factors determine which genetically susceptible individuals will be affected. Nutrition and physical activity (exercise) are two of the most important environmental factors in maintaining health and well being.

Each human being, in being unique, is exceptional in some way. Individuality is determined by genes, constitutional factors (age, sex, developmental socio-economic status, occupation, education, time, geography, and climate). Genetic variation is due to variants at a single locus, or polymorphisms, that form the basis of human diversity, including the ability to handle environmental challenges. How extensively variable the human species is depends on the methods used for the determination of variability. At the DNA level, there is a 
great deal of variation, whereas at the level of protein diversity, there is much less. In all animals, including humans and practically all other organisms examined, $30 \%$ of loci have polymorphic variants in the population. An average individual is heterozygous at about $10 \%$ of the loci. Alleles that confer selective advantage in the heterozygous state are likely to have increased in prevalence because of positive selection acting on variants. Changes in the nutritional environment and the type and degree of physical activity affect heritability of the variant phenotypes that are dependent, to a lesser or greater degree, on these environmental variables for their expression.

Genetic variation influences the response to diet. Nutrients and physical activity influence gene expression. In many conditions, proper diet and exercise have similar beneficial effects, and their effects may be additive. Because of differences in gene frequency, dietary habits, and activity levels, universal dietary and physical activity recommendations are not appropriate. Instead, knowledge of specific genes and response to exercise and diet should guide advice for health in the prevention and management of chronic diseases.

\section{Diet}

The purpose of diet is to supply energy and nutrients required for optimal health. Energy intake must be balanced against physical activity. Over 800 million humans are chronically energy deficient, but obesity is rampant in many industrialized societies.

\section{Macronutrients}

Fat is a concentrated energy source, but in affluent populations, excess fat promotes chronic degenerative diseases. In such circumstances, total fat intake should be reduced, mainly by decreases in saturated and trans fatty acids. In energy-deficient populations, an increased fat intake may be necessary to enhance energy availability and to insure absorption of fat soluble vitamins, but such increases should avoid adding saturated fats where practicable. All populations need essential polyunsaturated fatty acids for mental and cardiovascular health. An omega-6:omega-3 fatty acid ratio of 4:1 or less appears desirable.

Carbohydrate containing foods and soluble and insoluble fiber are needed for energy intake and normal bodily function.

Protein intake should be adequate for normal growth and development and in adults for maintenance of body structures.

\section{Micronutrients}

Adequate balanced micronutrient intake should be provided commensurate with emerging understanding of their need. Since the most extensive nutritional 
influences throughout the world are related to inadequacies of micronutrients, special attention should be directed to correcting these deficiencies: 2 thousand million persons are anemic and 1 thousand million are at risk of iodine deficiency. 40 million children suffer vitamin A deficiency. Understanding of micronutrient functions is currently increasing, and health workers should keep up-to-date with this new knowledge regarding both deficiencies and optimal requirements, e.g. the need for unitary ratios of calcium and magnesium in the diet. The variety of foods in the diets helps to maintain adequate micronutrient intake. Most populations would benefit from an increased intake of fruits and vegetables.

\section{Physical Activity}

A wealth of scientific reports points to the inescapable conclusion that human fitness and health improve when sedentary individuals begin to exercise. Although low physical activity levels most frequently occur in more industrialized, affluent nations, this behavior is becoming increasingly common in developing countries as well. Because mechanization and industrialization have reduced occupational physical activity levels, a need exists to supplement with additional daily physical activities designed to improve health and fitness.

A wide variety of fitness parameters, including aerobic capacity, muscular strength and endurance, coordination, flexibility and body composition improve with increases in activity levels. Perhaps more importantly, indices of human health also improve. Three of the most common chronic degenerative diseases of westernized nations (hypertension, coronary heart disease, and noninsulin-dependent diabetes mellitus) are increasingly being recognized as diseases of insulin resistance. In all three cases, physical activity clearly has been shown to reduce the severity, and outcome of these diseases. Physical activity also has a well-known role in preventing and reducing obesity and also exerts a beneficial influence upon insulin metabolism. Furthermore, increased levels of physical activity positively impact virtually all chronic diseases, including, but not limited to stroke, peripheral artery disease, coronary heart disease, chronic obstructive pulmonary disease, osteoporosis, and some forms of cancer. For previously sedentary individuals, even nontaxing physical activities such as walking, gardening, bicycling, and swimming can elicit improved health, and reduce all causes of morbidity and mortality. Table 1 lists the types of physical activity. Sports training physical activities should include daily training programs in preparation for competition. Health-promoting physical activities aim at promoting growth, improving body functions and protecting from illness. Exercise prescription (regimen) as a means of treating or reversing various diseases should be considered as an essential therapeutic component. 
Table 1. Defining physical activity

$1 \quad$ Nonlabor daily physical activities

Feeding

Bodily functions (e.g. temperature regulation, heart rate, breathing rate)

All daily nonlabor minimum physical activities necessary for life maintenance

2 Labor physical activities

Industrial

Agriculture

Carpentry

Homecare, etc.

3 Leisure-recreational (exercise), low-to-moderate intensity of physical activities

Walking

Dancing

Hiking

Bowling

Cycling

Golf, etc.

\section{Education}

Education about nutrition and physical activity needs to be adapted to each country and to different populations and cultures. Education about the beneficial physical and psychological effects of proper nutrition and physical activity in health and disease needs to be directed at all age groups - children, adults, and the elderly - since research has shown that awareness of the benefits of physical activity is correlated with actual physical activity. Education needs to address the detrimental effects of sedentary life-styles, undernutrition and malnutrition, in particular for children. Education about opportunities to obtain proper nutrition and to carry out physical activity is important in view of findings that actual increases in elective physical activity depend on accessibility.

Education should reach people through various channels - the mass media, print, television, and radio - at worksites, and in the community in order to reach everybody in the population. Another means to achieve education would be through role models in the family, schools, sports, and entertainment. Institutions such as schools can set examples for proper nutrition and physical activity. The food and sports foods industry needs to be cognizant of the scientific evidence regarding optimal nutrition and physical activity levels. Another means of education would be the labelling of the nutritional composition of all foods sold.

There is a particular need for education of health professionals and health workers, nutrition and sport scientists, and educators. 


\section{Declaration}

(1) Nutrition and physical activity interact in harmony and are the two most important positive factors that contribute to metabolic fitness and health interacting with the genetic endowment of the individual. Genes define opportunities for health and susceptibility to disease, while environmental factors determine which susceptible individuals will develop illness. Therefore, individual variation may need to be considered to achieve optimal health and to correct disorders associated with micronutrient deficiency, dietary imbalance and a sedentary lifestyle.

(2) Every child and adult needs sufficient food and physical activity to express their genetic potential for growth, development, and health. Insufficient consumption of energy, protein, essential fatty acids, vitamins (particularly vitamins A, C, D, E and the B complex) and minerals (particularly calcium, iron, iodine, potassium and zinc), and inadequate opportunities for physical activity impair the attainment of overall health and musculoskeletal function.

(3) Balancing physical activity and good nutrition for fitness is best illustrated by the concept of energy intake and output. For sedentary populations, physical activity must be increased; for populations engaging in intense occupational and/or recreational physical activities, food consumption may need to be increased to meet their energy needs.

(4) Nutrient intakes should match more closely human evolutionary heritage. The choice of foods should lead to a diverse diet high in fruits and vegetables and rich in essential nutrients, particularly protective antioxidants and essential fatty acids.

(5) The current level of physical activity should match more closely our genetic endowment. Reestablishment of regular physical activity into everyday life on a daily basis is essential for physical, mental and spiritual well-being. For all ages and both genders the physical activity should be appropriately vigorous and of sufficient duration, frequency, and intensity, using large muscle groups rhythmically and repetitively. Special attention to adequate nutrition should be given to competitive athletes.

(6) The attainment of metabolic fitness through energy balance, good nutrition and physical activity reduces the risk of and forms the treatment framework for many modern lifestyle diseases such as diabetes mellitus, hypertension, osteoporosis, some cancers, obesity, and cardiovascular disorders. Metabolic fitness maintains and improves musculoskeletal function, mobility, and the activities of daily living into old age.

(7) Education regarding healthy nutrition and physical activity must begin early and continue throughout life. Nutrition and physical activity must be interwoven into the curriculum of school age children and of educators, nutritionists 
and other health professionals. Positive role models must be developed and prompted by society and the media.

(8) Major personal behavioral changes supported by the family, the community, and societal resources are necessary to reject unhealthy lifestyles and to embrace an active lifestyle and good nutrition.

(9) National governments and the private sector must coordinate their efforts to encourage good nutrition and physical activity throughout the life cycle and thus increase the pool of physically fit individuals who emulate the Olympic ideal.

(10) The ancient Greeks (Hellenes) attained a high level of civilization based on good nutrition, regular physical activity, and intellectual development. They strove for excellence in mind and body. Modern men, women, and children can emulate this Olympic ideal and become swifter, stronger and fitter through regular physical activity and good nutrition.

\section{Distribution of the Declaration}

The declaration has been published worldwide in newsletters, magazines and journals. It has been translated into the Olympic languages of Chinese, French, Greek, Russian and Spanish. The ten points of the declaration have been printed in these languages. The Executive Committee wishes to encourage the translation and distribution of the declaration worldwide. The copyright is held by the Executive Committee of the Conference.

The declaration was developed at Ancient Olympia, May 28-29,1996 by the following persons:

Alexander Leaf, MD (Cochairman), William Clay, FAO, United Nations USA Loren Cordain, PhD, USA

Peter G. Bourne, MD (Cochairman), S. Boyd Eaton, MD, USA USA, UK Gilman Grave, MD, USA

Richard B. Birrer, MD Philip R. Lee, MD, USA

(Secretary), USA Regina Casper, MD, USA Ji Di Chen, MD, China Konstantinos N. Pavlou, ScD, Greece Catherine Siandwazi, Tanzania, UK Artemis P. Simopoulos, MD, USA

\section{References}

1 Simopoulos AP (ed): Proceedings of the First International Conference on Nutrition and Fitness. Am J Clin Nutr 1989;49(suppl):909-1124.

2 Simopoulos AP, Pavlou KN (eds): Volume I. Nutrition and Fitness for Athletes. Proceedings of the Second International Conference on Nutrition and Fitness. World Rev Nutr Diet. Basel, Karger, 1993, vol 71 . 
3 Simopoulos AP (ed): Volume II. Nutrition and Fitness in Health and Disease. Proceedings of the Second International Conference on Nutrition and Fitness. World Rev Nutr Diet. Basel, Karger, 1993, vol 72.

4 Simopoulos AP (ed): Volume I. Nutrition and Fitness: Evolutionary Aspects, Children, Health, Policies and Programs. Proceedings of the Third International Conference on Nutrition and Fit ness. World Rev Nutr Diet. Basel, Karger, 1997, vol 81.

5 Simopoulos AP, Pavlou KN (eds): Volume II. Nutrition and Fitness: Metabolic and Behavioral Aspects in Health and Disease. Proceedings of the Third International Conference on Nutrition and Fitness. World Rev Nutr Diet. Basel, Karger, 1997, vol 82.

6 Simopoulos AP, Pavlou KN (eds): Volume 1. Nutrition and Fitness: Diet, Genes, Physical Activity and Health. World Rev Nutr Diet. Basel, Karger, 2001, vol 89.

7 Simopoulos AP, Pavlou KN (eds): Volume 2. Nutrition and Fitness: Metabolic Studies in Health and Disease. World Rev Nutr Diet. Basel, Karger, 2001, vol 90. 


\title{
Positive Health: Exploring Relevant Parameters
}

\author{
Elizabeth Ferris \\ Department of Nutrition and Dietetics, King's College London, London, UK
}

This year we are celebrating not only the Fifth International Conference on Nutrition and Fitness with its strong connections with Greece but also the return of the Olympic Games to the city where the modern Olympics was born over a century ago in 1896. To me as an Olympian this conjunction of the Conference with the Athens 2004 Olympics is of special importance and augments the honour of being invited to open the conference.

There is a saying, 'Once an Olympian, always an Olympian', - it was coined because of the unique experience competing in the Olympic Games has come to mean. There are 100,000 Olympians from over 200 countries around the world. They form a unique resource, a valuable asset to sport and to the Olympic Movement. It is by Olympians' efforts and talents that the Olympic Games come alive in the stadium, the pool and the sports arenas. Without them there would be no Games. So it was in 1995, to recognise the contribution Olympians make and provide opportunities for former athletes to continue to play a part in the Olympic Movement, that, with the support of the International Olympic Committee, the World Olympians Association was created of which I am a co-founder and Vice President.

My involvement in sport influenced the choices I made as a doctor. As a medical student at the Middlesex Hospital Medical School at London University, I realised that I was more interested in health than disease and my professional career has followed a path of seeking out ways in which we can explore our capacities to create and maintain our own physical and mental health. 
My participation at this conference in a way brings together my several identities - on the one hand as a former elite sportswoman and on the other as a doctor interested in preventive medicine and holistic health, especially nutrition and physical fitness.

The positive value to health of physical activity and nutrition is as old as civilization itself. The case for good food as a means of enjoying a long and healthy life is in no doubt. It was part and parcel of life for the ancient Greeks and when Hippocrates said, 'Let food be thy medicine and medicine be thy food', he was expressing something that instinctively people through the ages have sensed must be true. Food is far more than simply a means of staying alive. The song, 'Food, glorious, food, there's nothing quite like it', from the musical, 'Oliver', based on Charles Dickens' book, Oliver Twist, says it all.

The health benefits of physical exercise too have been widely proclaimed over the centuries. The 18th century English poet, John Dryden, pre-empted modern self-help devotees when he advised, 'The wise for cure on exercise depend; God never made his work for man to mend.' So much for his faith in the healing powers of doctors.

The ancient Greeks had a thorough knowledge of high-level physical training and knew that you can have too much of a good thing. We may think overtraining is a modern phenomenon considering the enormous pressures professional athletes are under to perform well. But two and half millennia ago, Hippocrates expressed his concern about its detrimental effects when he wrote: 'Physical conditioning is at risk when exercise is at very high levels.'

Aristotle agreed. He warned of the dangers of exposing young children to excessive training, pointing out that it undermined their powers of endurance and scuppered young athletes' ambitions of Olympic victory later on as adults ${ }^{1}$.

The ancient Greeks lived in a Mediterranean paradise awash with highly nutritious green, yellow and red vegetables and fruit, nuts, olives, fish, and, of course, wine. With the warm climate and their love of sport it is little wonder that the concept of positive health through nutrition and physical fitness originated in Greece.

In my address today I'd like to explore the parameters of positive health, starting with a little of the history of the Olympic Games to draw a connection between the aspirations of the ancient Greeks and the aims of the creators of the modern Olympics in 1896 that revived those aspirations and that, right up to the present day, remain an important objective of the Olympic Movement. Using

\footnotetext{
${ }^{1}$ 'The disadvantages of excessive training in early years are amply proved by the list of Olympic victors; not more than two or three of whom won a prize both as boys and as men. The discipline to which they were subjected in childhood undermined their powers of endurance.' [Aristotle, Politics, Book VIII]
} 
this connection as a stepping stone, I will dip into recent scientific research that provides evidence in support of Hippocrates' analysis of positive health. I will touch on public health issues surrounding the global pandemic of obesity and its related serious health risks. Finally, looking to the future, I will suggest how our growing knowledge of the human genome is likely to impact on how we could maximize our potential for a healthy life.

More than fourteen hundred years after the last ancient Olympic Games were held in the 4th century AD, the idea that physical activity was essential to live a healthy life re-emerged, in particular in Victorian England on the playing fields of boy's public schools. The concept that to be sound of mind you needed to take care of your physical health formed the basis for the physical education movement that grew up in the 19th century ${ }^{2}$. But the movement did not focus only on physical health. In tune with the ancient Greek approach, it embodied moral, social and cultural principles as well. The physical education movement provides a link between the ancient Greek cultural commitment to sport on the one hand and the creation of the modern Olympic Games here in Athens in 1896 on the other.

Accepted wisdom has it that the modern Olympics was the brain-child of a French aristocrat, Baron Pierre de Coubertin. But, as with so much in history, the story was rather more complex and interesting. Before Coubertin was born, a wealthy Greek called Zappas had made unsuccessful attempts to resurrect the ancient Games in Greece. Meanwhile, in a tiny town in England called Much Wenlock, an English country surgeon, Dr. William Penny Brookes, from 1850 onwards, organised annual Olympic-style sporting festivals. He called them the Wenlock Olympian Games. Why would a rural doctor spend his time and effort, and no doubt his own cash, in creating a re-enactment of the ancient Olympic Games in a field in rural Shropshire - and who competed in them? Dr. Brookes was a philanthropist who believed that everyone in the community, not only the moneyed classes, was entitled to education and access to healthy leisure pursuits. He campaigned for physical education for children and petitioned Parliament to make it compulsory in all elementary schools [1]. Like the ancient Greeks, he believed that sporting participation produced moral and intellectual benefits as well as contributing to physical health.

Dr. Brookes was also a Hellenist, a lover of all things from ancient Greece, and he organised his Olympian Games as nearly as possible to the ancient Olympics. The medals awarded to the winners bore the portrait of Nike, the Greek Goddess of victory, with a quotation from Pindar, the classical poet of the Olympic Games.

\footnotetext{
${ }^{2}$ The concept of a sound mind in a healthy body, mens sana in corpore sano, originated from the Roman satirist, Juvenal AD c.60-c.130.
} 
Dr. Brookes' Olympian Games had been in full swing for 40 years before Pierre de Coubertin, who was a young educationalist on a mission for the French government to research foreign systems of physical education, went to Much Wenlock in 1890 to meet Dr. Brookes and see his Games in action. Coubertin was deeply impressed and immediately recognised a kindred spirit in the country doctor. The two men shared a passionate commitment to physical recreation, not only for its health benefits but also for its moral and social value, values that today characterise what is called Olympism. After his meeting with Brookes, Coubertin wrote: '.. if the Olympic Games that modern Greece has not yet been able to revive still survive today, it is not due to a Greek but to Dr. W.P. Brookes. It is he who inaugurated them 40 years ago and it is still he, now 82 years old but still alert and vigorous, who continues to organise and inspire them' $[2,3]$.

The two men shared a vision of recreating the Olympic Games in modern times. As history reveals, Coubertin succeeded in this ambitious venture but sadly Brookes did not live to see the dream become a reality; he died in 1895 aged 87 having given his blessing to Coubertin's international vision.

The important thing to recognise is that for Brookes and Coubertin the Olympic Games were a means by which universal physical education for all could be attained. I maintain that this is just as true today as it was in 1896. Notwithstanding the ways in which elite sport has changed of late, due in part to professionalism and commercialism, and drug-taking, the Olympic Games have the capacity to inspire young people at the grass roots level to participate in sport and physical activities. I remember the overwhelming rush of young girls wanting to practice gymnastics after Olga Korbut entranced the world with her performance in Montreal in 1976. The power to awaken such interest on a global scale is unique to the Olympic Games because of the extra dimension that the Olympics possesses compared with other international sporting events embodied in the philosophy of Olympism ${ }^{3}$. Their contribution to positive health lies in the potential to encourage people, especially children, to become more physically active ${ }^{4}$. And, there are added bonuses in being involved in sport that I will come to a little later.

${ }^{3}$ The International Olympic Committee, in the Olympic Charter (in force as from 4 July 2003) under Fundamental Principles on $\mathrm{p} 9$ defines Olympism as follows: 'Olympism is a philosophy of life, exalting and combining in a balanced whole the qualities of body, will and mind. Blending sport with culture and education, Olympism seeks to create a way of life based on the joy found in effort, the educational value of good example and respect for universal fundamental ethical principles.'

${ }^{4}$ The story of the rise of women in the Olympic Games further illustrates my point. At the first modern Olympics in 1896, there were no women because Baron De Coubertin thought the Games should remain 'the exaltation of male sport'. The traditional attitude was that women 
I'd like to turn now to the immense contribution the scientific community has made to the issue of positive health. Let's fast forward to Britain in 1953, the year when, as the nation watched the coronation of Queen Elizabeth II in Westminster Abbey, news of the successful conquering of Mount Everest by the British expedition lead by Sir Edmund Hilary was celebrated, and just a few months later, arguably the most important sporting event of the 20th century was held when Roger Bannister conquered the four-minute mile.

On the health front, Fleming's discovery of penicillin and its development as an antibiotic by Lord Florey, plus a mass vaccination programme saw the gradual demise of infectious diseases as a principal cause of death. Fifty years ago, medical concerns turned to focus on non-communicable diseases, in particular coronary heart disease (CHD), the major cause of premature death in the world. Morris' seminal study [4] showed that conductors on the famous London red double-decker buses had significantly less coronary artery disease than the drivers of the buses. The health benefits of being a conductor were attributed not unreasonably to the fact that they were much more physically active than sedentary drivers. Incidentally, anyone hoping to take up this healthy job in future will be disappointed - these wonderful Red Routemasters, recognised worldwide as icons of London, are being phased out in favour of buses with just a driver whose only exercise is to press a button to open and close the doors automatically. Alas, for us passengers, no more running and jumping on the platform at the back of moving buses - a game Londoners love to play. An opportunity for a little bit of exercise in the normal course of life itself will be

were biologically unsuited to taking part in sport and, anyway, it was a male domain - a view that prevailed well into the 20th Century.

It didn't take long for women to overturn the IOC's entrenched view. Women golfers, tennis players and sailors took part in the second Games in 1900 and women have participated in every Olympic Games since. Throughout the past 100 years, more and more women have competed in the Olympics; in Athens 2004 the proportion of women to men will for the first time approach parity. Of the 10,000 athletes women will make up approximately $41 \%$ and will compete in all but boxing and baseball.

A positive by-product of more women athletes in the Olympics is the growth of women's sport around the world, especially in developing countries. The challenges women face in many countries relating to religion, culture, education, poverty, and health take precedence over concerns about sport. And yet, notwithstanding these social barriers and inequality, women and girls are increasingly playing sport. There is still a long way to go but you have to admit that progress is being made when you see that in Afghanistan, where until recently women were hardly allowed to leave their homes, women are playing mixed table tennis matches in public, and in Morocco, hundreds of women and girls turn up annually for a roundthe-houses run in Casablanca. From a public health point of view, perhaps the most important fact is that physically active mothers are most likely to produce physically active children and physically active children are most likely to maintain the habit into their adult years. 
lost. No matter - perhaps we can make up for it by climbing the stairs in our office buildings - if we can find them! This remark may sound flippant, but it is relevant to my theme because it highlights the fact that opportunities for activity in our everyday lives, that we used to take for granted, are becoming less and less common for reasons over which we have little or no control.

The benefits of an active lifestyle were further confirmed in the 1980s by Paffenbarger and colleagues. Harvard alumni who took regular exercise, outputting 2,000 kcal or more per week, had a 39\% lower risk of developing coronary heart disease and of death from the disease than their less active classmates [5]. We also now know, where a healthy heart is concerned, it is the intensity of the exercise that matters [6].

Coronary heart disease is clearly a lifestyle disease with smoking and physical inactivity top of the list of risk factors, and we know that exercise is beneficial. What about the effects of diet? Recent research has revealed that a nutritional substance - folic acid, one of the B vitamins - gives considerable protection in heart disease by lowering homocysteine levels in the blood. In addition, folate protects against a wide array of other serious diseases including cancer, dementia and birth defects [7]. It has many diverse biological properties expressed through a number of crucial gene pathways and has even been cited as the panacea of the 21 st century. The effect of folate research has been to open up new avenues of intervention with vitamins and other nutrients in disease prevention, and a new area of research has been identified - nutrigenomics, the study of the links between nutrition and gene function. Nutrigenomics fits very well with what Hippocrates knew instinctively when he spoke of the powerful effects of various foods and physical exercise on man's primary constitution.

In addition to the protective effect of exercise in coronary heart disease, physical activity has been shown to be significant in other serious diseases that are major causes of death in the modern world - diabetes, osteoporosis, obesity related conditions and cancer ${ }^{5}$. The amount and type of exercise recommended varies. In obesity, where weight loss is the goal, any increase in energy output is desirable. The Chief Medical Officer in the UK just a few weeks ago, in an

${ }^{5} \mathrm{An}$ extraordinary story of bravery and endurance that raises important questions about the relationship of exercise to cancer is that of Jane Tomlinson, a young British mother who, in 2000, was diagnosed with terminal bone cancer and told she had just 6 months to live. Since then, Jane has run three marathons, completed an 'Iron Man' event and recently cycled 2,500 miles from Rome to Yorkshire in the North of England where she lives. No-one knows the role vigorous exercise has played in prolonging her life, or that of the professional cycling phenomenon, Lance Armstrong, who had testicular cancer and went on after treatment to win the Tour de France six times. 
attempt to arouse the largely sedentary population to 'get up and go', produced a report entitled, 'Physical Activity and Health' in which he recommended vacuuming and ironing as good examples of moderate exercise. Whilst this may seem like too little too late, it is claimed that $30 \mathrm{~min}$ of moderate exercise 5 times a week is enough to prolong life.

We also know that exercise has positive effects on mood and feelings of mental well-being. Fascinating research from the Salk Institute suggests that physical activity has a positive effect on brain plasticity. There are stem cells in the adult brain that produce new nerve cells in the dentate gyrus of the hippocampus, an area associated with memory. Physical activity positively promotes this neurogenesis - in running mice at least [8]. For those of us who have those occasional 'senior moments', like when you find yourself in the cupboard under the stairs and cannot for the life of you remember what you've gone there for, a little light running on the spot to stimulate a few new brain cells may help you to remember what on earth you're doing there - if you can remember the original piece of research! In fact, this is a particularly productive line of research in support of physical activity in the aged. We now have evidence that exercise combined with a diet rich in nutrients, in particular folic acid, could help stave off symptoms of dementia and Alzheimer's disease in increasingly ageing populations.

The effects of nutrition on mental function and behaviour are equally interesting. Young adult prisoners showed a remarkable reduction in antisocial behaviour when their diets were supplemented with vitamins, minerals and essential fatty acids [9]. Poor nutrition, on the other hand, has alarming effects. Young schoolchildren who went without breakfast missed out in more ways than one. Three hours into school, the children had powers of attention as poor as an adult who had had a slug or two of whisky or a tranquiliser. And they did equally badly when they had just a glucose drink. With cereal for breakfast, however, they showed an enormous improvement [10].

With the scientific body of knowledge expanding, the case for physical activity coupled with good food for a long and healthy life is made and is in no doubt. And yet, hardly a day goes by without another report of the growing pandemic of obesity across the globe. Population surveys show that the world is getting fatter and the incidence of Type 2 diabetes is increasing at an alarming rate, in particular, and perhaps most disturbingly, in young children.

In our highly technologically developed modern world in which the need to extend ourselves physically in the normal course of our lives is diminishing day by day, our lifestyles have changed radically during the past 50 or more years. As obesity levels rocket, it seems reasonable to blame the modern diet high in fat, sugar and salt for the increases. This is hardly new: Plato was highly critical of those who were a nuisance to their doctors because of leading an 'idle life' and 'filling our bodies with gases and fluids like a stagnant pool' [11]. 
Counter-intuitively, children it appears are actually eating less today, not more, than they used to eat $[12,13]$. Children are getting fatter because they are much less active than they used to be and their energy intake in the food they eat is greater than the energy they expend in physical activity. The reasons are largely cultural: more car journeys with less walking, parental concerns about security and safety that restrict where and when children can play, and, in particular, television watching and computer games are all cited as reasons for inactivity in children across the globe [14], even in China where until recently you would never see a fat person let alone an obese child [15]. Along with TV watching goes snacking on high-density junk food and fizzy drinks that further contribute to the greater energy intake/lesser energy output problem [16].

The emphasis, especially in the media, is predominantly on what children eat because it's obvious to see the outcome and it is easy to make value judgements about children who are fatter than we think they ought to be. In fact, in health terms, it is almost certainly better to be active, fit and a bit fat than lazy and lean.

Perhaps the most alarming information to come to light concerning this growing problem is in a report of the International Council of Sport Science and Physical Education (ICSSPE) that states: 'school physical education is in a perilous position in all continental regions of the world' [17]. PE has a low priority in school curricula, and is starved of funding, materials, time and teachers. The future of PE looks bleak. Governments are giving out confusing mixed messages. On the one hand, they are advising children to do more exercise whilst on the other hand making it obvious that physical education is a Cinderella subject on the school curriculum deserving few resources. It doesn't make any sense.

On a more personal level, good food and good eating initiatives are sprouting as public interest in nutrition grows especially in developed countries. For example, organic farming is expanding in Europe to counter the use of additives and pesticides, alongside a popular anti-GM crops drive that has resulted in Monsanto cancelling its GM crop production programme in Europe. Another initiative is the slow food movement in Italy that has emerged as an antidote to the fast food culture in an attempt to replace it with old values of sitting down to meals with family and friends, and savouring good, wholesome nutritious food and wine. Children too benefit from this style of eating. Children who eat meals with their family consume more fruit and vegetables, fewer fizzy drinks and less fat in food both at and away from home [18].

Again, the ancient Greeks got it right. According to a recently published account of what Olympic winners eat in ancient Greece:

The main meal was dinner where the presence of family and friends and the consumption of wine were important elements. Dinners were rather prolonged 
during which people were eating, drinking wine with water and discussing current issues. (The term 'symposium' means 'drinking together with others') [19].

In the commercial world, if one can believe the stock quotes, the leisure industry is profiting from increasing membership of gym and fitness centres although the percentage of people in the UK who regularly exercise hardly reaches double figures, McDonald's, under pressure from the media and the public, is changing its image to provide more healthy salad and fruit options, and the vitamin and supplement industry is booming as people self-administer these products in an attempt to bolster their well-being.

In my early school days, I remember that the welcome mid-morning interval between writing and arithmetic was called playtime, and play we did. I suggest that, with respect to children at least, we need to put play back into physical activity. Perhaps, we need to change the terms we use; 'physical education' is a rather dry phrase, we could go back to using the word 'recreation' - it has a more pleasurable ring about it.

Perhaps a clue to how to appeal to children can be found in what youngsters like to do in their leisure time: they like to play computer games. Sony had a brilliant idea when they called their equipment Play Station. To me the title is an oxymoron. Sony used the word 'play' - which according to the Oxford English Dictionary (OED) means to move about swiftly; to fly, to dart to and fro; to frisk, to flit, to flutter, all words that exemplify what children do when they play - juxtaposed with the word 'station' which, according to the OED, means standing still, the opposite of motion. But the word 'play' is evocative and enticing ${ }^{6}$. Why are computer games so beguiling to children? Is it because they provide positive feedback, enjoyment, accomplishment, the possibility of winning, and even applause for success - all the things an athlete gets, or hopes to get, from sport?

But, not all children are good at sport and many are alienated from participating especially when the emphasis is on competition and performance. Even children who show an aptitude for one sport, gymnastics say, may not show any talent for another, a ball game, like soccer. I started my sporting life as a swimmer but I became bored with the training. It didn't suit my personality and if the opportunity had not arisen to change to diving, a much more acrobatic sport, I am sure I would have given up. I heard a similar story from an Olympic swimming champion. He was hopeless at school sport - last in cross-country running, no eye-to-ball coordination. One day he fell through a plate glass window and severed a tendon in his calf, couldn't run and so, fortuitously, took up swimming, loved it and made it to the very top winning 2 Olympic gold medals. The moral of his and my stories is

${ }^{6}$ Montaigne said 500 years ago, 'It should be noted that children at play are not playing about; their games should be seen as their most serious-minded activity.' 
that if we had not had the good fortune each to find our own sporting niche neither of us would have won our Olympic medals. Unless options are available to be tried and tested by the individual, a child could be put off sport, and by association, physical activity, for the rest of his or her life - and very possibly to the detriment of their health.

The key question is how people can be enticed into changing their lifestyles to incorporate physical activity and good nutrition into their normal everyday lives. The World Health Organisation recently presented its global strategy to improve public health through healthy eating and physical activity. Governments are considering what public health initiatives they can provide to help solve the problem. In 2004, a British Parliamentary Health Committee published a report [20] in which it recommended 80 measures including a ban on the promotion of sugary drinks and snacks in schools, curbs on advertising junk foods on television in particular during children's programmes, health warnings and clearer labelling on foods, and new building developments to feature cycle paths, walkways and playing fields. All good ideas - but will they work? And will they work in time to defuse the ticking time bomb of poor health, shortened life spans and premature death in the current generation of physically inactive children for whom obesity and its concomitant problems are becoming the norm.

To date, the health argument has not exactly been able to inflame the public's imagination. The cosmetic argument only carries weight with those vain enough to care. An alternative approach, it seems, is needed if public attitudes are to change. A possible clue may be gleaned from a fascinating study of the Pima Indians of Arizona [21]. Pima Indians suffer from high levels of obesity and diabetes. The study tested the efficacy of lifestyle interventions. One group of subjects, the Pima action group, had a mix of nutrition and physical activity active interventions. The other group, the Pima pride group, received printed leaflets about activity and nutrition but in addition they engaged in regular discussions on Pima culture and history. At the end of 12 months, the pride group was showing much more favourable results than the action group in terms of their health parameters - they had lost more weight and had more favourable blood glucose and insulin levels. It seemed that by boosting their pride in their Pima identity, almost as a side effect they were able to take more care of their health compared with those in the action group who only focussed on changing their diet and exercise. Did this effect have something to do with building up the pride group's self-esteem and respect for their Pima identity? I think so. It's possible to link the concepts of respect and self-esteem with autonomy [22]. Researchers have found that control at work, or the lack of it, i.e. lack of autonomy, is associated with increased health risks [23, 24].

I have touched on some complex issues in an attempt to suggest that the answers to the health problems we face do not lie in governments simply telling 
people to eat less and walk more, good as that advice may be. Something has to ignite a person's interest and that is why I have come back full circle to sport.

Sport for me, before I reached the elite level, was a complete experience. It provided me with a full social life, good friends who, 40 years later, I am still in touch with, travel, teamwork, a sense of achievement and how to deal with failure as well as success. The actual activity, the experience of diving, was completely personal. But it was the context in which I did it that provided the ground in which I grew up and thrived. If, amongst the myriad of choices sport has to offer, a person, in particular a child, can find something to illuminate their curiosity and suit them mentally as well as physically, sport is an activity that, in the broadest terms, can offer a rewarding lifestyle with healthy by-products. Active children are more likely to become active adults, and physically fit and active adults have lower risks of heart disease, diabetes and cancer.

Turning now to the future, scientific studies and public health initiatives I've highlighted show that, when reaching for ways of dealing with chronic non-communicable diseases, advice on what lifestyle changes an individual can make has tended to focus on just two variables - dietary habits and patterns of physical activity (with smoking as well in the case of CHD). The underlying assumption has been that these are possibly the most important or even the only parameters in a person's individual make-up relevant to health (and ill health). I suggest that this is a very restricted view. My own view can be summarised as follows:

(1) Genetic factors play at least as important a role as exercise and diet. Moreover, genetic constraints and regulation influence individual potential to respond to exercise and dietary factors. For example, the Finnish Olympic champion cross-country skier, Eero Maentryanta, was a medical mystery. $\mathrm{He}$ had $15 \%$ more red blood cells than normal and some were convinced he was blood doping although there was no evidence. The mystery was solved by Lodish and colleagues at the MIT when they discovered that Maentryanta and others in his family had a genetic mutation that accounted for the high levels of red blood cells [25].

Another study showed that a single gene - dubbed the 'performance gene'may influence an athlete's propensity to excel at either sprinting or long distance running. The gene, which encodes for an enzyme - angiotensin-converting enzyme (ACE) -, researchers believe determines whether an individual grows more 'fast twitch' or 'slow twitch' muscles fibres [26].

With respect to obesity, O'Rahilly's group at Cambridge together with other researchers have found a genetic connection between proneness to obesity and PPARy genotype [27]. In simple terms, their work shows that some people have a genetic propensity for obesity whilst others don't. This corresponds to our intuition. We've all said at some or other, 'Lucky old so-and-so - he can eat anything and stay thin'. 
We can say something similar regarding the connection between fitness and health. Evidence is all around us of very fit people who succumb to illness and die. Look at Jim Fixx, who started the jogging craze; a very fit man who died suddenly and prematurely from a heart attack. At the other end of the health spectrum is the Australian, Shane Gould, who at 15 years of age was a multiple Olympic champion and the supreme swimmer in the world. This year, 30 years on, at age 47, she returned to swimming and qualified for the Australian Olympic trials. She has to have an extraordinary genetic makeup.

These examples illustrate how an individual's genotype may determine both potential for protection from developing disease as well as the risk of developing disease $^{7}$. We know, for instance, that smokers vary in their risk of developing lung cancer and coronary heart disease. It is possible that within a few years we may be able to characterise people according to their genotype, and programmes of dietary and exercise interventions could be tailor-made to the individual.

(2) Future research will eventually lead to an awareness of the importance of other variables apart from diet and exercise. This in turn will eventually expand our understanding, not only of the number of variables involved, but also how these variables relate to one another.

In my ideal world, we would eventually end up with a detailed algorithm that would specify all the variables involved and relate them to each other in a quantifiable, indeed, mathematical, way. Statisticians are already grappling with producing such a mathematical equation. How wonderful it would be if a formula such as $2(A+1 / 2 B+2 / 3 C-D \ldots n) / 4$ specified the exact relationship of all the relevant variables in a unique equation for each individual, where, say, $\mathrm{A}$ is exercise, $\mathrm{B}$ is diet, $\mathrm{C}$ is genotype, $\mathrm{D}$ is hitherto unknown variable and $\mathrm{n}$ is all future relevant variables - along the lines that Hippocrates suggested, 'the season of the year, the changes of the winds, the age of the individual and the situation of his home' ...and any number more.

The human genome project has opened wide the potential for the kind of outcomes I am suggesting. The future is exciting. We are very fortunate to have leaders in these fields of research here at our meeting and I wish us to have a wonderful and stimulating conference.

Thank you all for your attention.

Dr. Elizabeth Ferris, 2004

${ }^{7}$ To see why diet and exercise cannot be the only variables that are relevant to health see: Campos P: The Obesity Myth: Why America's Obsession with Weight Is Hazardous to Your Health. New york, Gotham Books, 2004. 


\section{References}

1 Anthony D: Minds, Bodies and Souls: A Trilogy of the British Olympic Heritage Network. London, British Olympic Association, 1994.

2 de Coubertin P: Les Jeux Olympiques à Much Wenclock; In: La Revue Athlétique, 1, No.12 (December 1890). WOS 2nd MB, p 182.

3 Mullins S: British Olympians: William Penny Brookes and the Wenlock Games. London, British Olympic Association, 1986.

4 Morris JN, Heady JA, Raffle PAB, Roberts CG, Parks JW: Coronary heart disease and physical activity at work. Lancet 1953;ii:1053-1057, 1111-1120.

5 Paffenbarger RS, Hyde RT, Wing AL, Steinmetz CH: A natural history of athleticism and cardiovascular health. JAMA 1984;252:491-495.

6 Tanasescu M, Leitzmann MF, Rimm EB, et al: Exercise type and intensity in relation to coronary heart disease in men. JAMA 2002;288:1994-2000.

7 Lucock MD, Yates Z: A differential role for folate in developmental disorders, vascular disease and other clinical conditions: The importance of folate status and genotype; in Massaro EJ (ed): Folate and Human Development. Totawa, Humana Press, 2001, pp 263-298.

8 van Praag H, Christie BR, Sejnowski TJ, Gage FH: Running enhances neurogenesis, learning, and long-term potentiation in mice. Proc Natl Acad Sci USA 1999;96:13427-13431.

9 Gesch CB, Hammond SM, Hampson SE, Eves A, Crowder MJ: Influence of supplementary vitamins, minerals and essential fatty acids on the antisocial behaviour of young adult prisoners. Brit. J Psychiatry 2002;181:22-28.

10 Wesnes KA, Pincock C, Richardson D, Helm G, Hails S: Breakfast reduces declines in attention and memory over the morning in schoolchildren. Appetite 2003;41:329-331.

11 Plato: The Republic. Part 111: Education, Book 111, Physical Education. London, Penguin Classics, 1987, p 109.

12 National Diet and Nutrition Survey: Young People aged 4-18 Years. London, Stationery Office, 2000.

13 Durnin JGVA: Physical activity levels - past and present; in Norgan N (ed): Physical Activity and Health. Cambridge, Cambridge University Press, 1992, pp 20-27.

14 Dietz WH: The obesity epidemic in young children. BMJ 2001;322:313-314.

15 Cheng TO: Obesity in Chinese children. JRSM 2004;97:254.

16 Giammatei J, Blix G, Marshak HH, Wollitzer AO, Pettitt DJ: Television watching and soft drink consumption. Arch Pediatr Adolesc Med 2003;157:882-886.

17 Hardman K, Marshall I: World-wide Survey of the State and Status of School Physical Education. ICSSPE Report, 2002.

18 Gilman MW, Rifas-Shiman SL, Frazier AL, Rockett HRH, Camargo CA Jr, Field AE, et al: Family dinner and diet quality among older children and adolescents. Arch Fam Med 2000;9:235-240.

19 Terkesidou L: The Golden Diet of the Ancient Olympic Winners. Athens, Kastaniotis Publishers, 2004.

20 House of Commons Health Committee: Obesity: Third Report of Session 2003-2004. Publication Parliament UK.

21 Venkat Narayan KM, Hoskin M, Kozak D, Kriska AM, Hanson AM, Pettitt DJ, et al: Randomized clinical trial of lifestyle interventions in Pima Indians: A pilot study. Diabet Med 1998;15:66F-72F.

22 Sennett R: Respect in a World of Inequality. New York, Norton, 2003.

23 Marmot MG, Bosma H, Hemingway H, Brunner E, Stansfield S: Contribution of job control and other risk factors to social variations in coronary hear disease. Lancet 1997;350:235-240.

24 Kuper H, Marmot M: Job strain, job demands, decision latitude, and the risk of coronary heart disease within the Whitehall II study. J Epidemiol Commun Health 2003;57:147-153.

25 'Whitehead finds answer to old puzzle' - article from MIT Tech Talk, May 17 1995. The work was reported in Cell. 
26 Montgomery H: Renin-angiotensin systems and human performance. Genes in Sport Conference, 30 November 2001, UCL School of Human Health and Performance.

27 Luan J, Browne PS, Harding DJ, O'Rahilly S, Chatterjee KVK, Wareham NJ: Evidence for genenutrient interaction at the PPARy locus. Diabetes 2001;50:686-689.

\section{Elizabeth Ferris, MBBS}

Department of Nutrition and Dietetics

King's College London, Franklin Wilkins Building

150 Stamford Street, London SE1 9NH (UK)

Tel +44 1367 860313, E-Mail elizabeth.ferris@kcl.ac.uk 